Almir Peštek ${ }^{1}$

Emina Resić ${ }^{2}$

Maja Nožica ${ }^{3}$
UDK 004.7:339.1>:336.12

Preliminary paper

Prethodno priopćenje

\title{
MODEL OF TRUST IN E-TRANSACTIONS
}

\begin{abstract}
Besides significant benefits, the trend of e-commerce development gives rise to a lot of challenges in terms of developing trust between the company and the consumer. A lack of trust leads to withdrawal from e-transactions. The paper is thus aimed at identifying and explaining the most important factors that affect the increase in users' trust in e-transactions. Besides an analysis of available papers in this area, a field research was conducted on a sample of 512 respondents in Bosnia and Herzegovina in order to develop a structural model of users' trust in e-transactions. Research findings confirm that the basic factors of an online trust model are: website usability, privacy, security, expected product performance, loyalty, and electronic management of customer relations (e-CRM).
\end{abstract}

Key words: e-transactions, e-commerce, trust

\section{INTRODUCTION}

In recent years, we have witnessed the growth in popularity and importance of ecommerce. E-commerce stands for any financial transaction that has been carried out electronically. It has become an important factor in international business and includes purchase and sale of all types of goods or services over the internet. E-commerce has enabled customers and producers around the world to meet in virtual marketplaces and complete transactions more efficiently. The internet and related technologies erase boundaries in terms of time and space and provide organizations with enormous business opportunities, and on the other hand - consumers have more choice.

Besides all the benefits that it brings to consumers, e-commerce also brings many complex problems which are closely related to ethical and legal issues. The exposure to multiple merchants and many options from around the world, together with new infrastructure for e-commerce leads to an increased risk. In the dynamic environment of e-commerce, many consumers are indeed faced with information overload and uncertainty. Lack of trust in online payment, privacy issues and adequate services created a psychological barrier when it comes to e-commerce. A key of success is not just a presence on the internet, or low price, but also the quality of the entire service, including interaction before, during and after the transaction.

Evidence suggests that consumers often hesitate to transact with web-based vendors because of uncertainty about vendor behavior or the perceived risk of having personal information stolen by hackers. Trust plays a central role in helping consumers overcome perceptions of risk and insecurity (McKnight, Choudhury \& Kacmar, 2002).

\footnotetext{
1 Assistant Professor, Department of Marketing, School of Economics and Business in Sarajevo, Trg Oslobođenja - A.Izetbegović 1, 71000 Sarajevo, Bosnia and Herzegovina, almir.pestek@efsa.unsa.ba

${ }^{2}$ Assistant Professor, Department of Quantitative Economics, School of Economics and Business in Sarajevo, Trg Oslobođenja - A.Izetbegović 1, 71000 Sarajevo, Bosnia and Herzegovina, emina.resic@efsa.unsa.ba

3 Account Executive, Mark In doo, Milana Preloga 19, 71000 Sarajevo, Bosnia and Herzegovina, maja@markin.ba
} 


\section{E-TRANSACTIONS AND TRUST}

E- transaction is an electronic exchange of values. All transactions have a degree of uncertainty about their outcome, and buyers cannot accurately predict whether a transaction will be fulfilled successfully. Successful fulfillment typically suggests that a seller delivers a product identical to the one promised, does so in a timely manner, and honors refund and product guarantees. In contrast, there are numerous possibilities that a transaction may not be fulfilled successfully due to seller or product quality uncertainty. For example, sellers can collect payment but not deliver a product (fraud), deliver a product that differs from the one advertised (lower quality, expired, or counterfeit products), refuse to accept payment and send a product (contract default), prolong product delivery, fail to acknowledge return, refund, and product guarantee policies, sell the buyer's private information or not protect the buyer's monetary information, among others. Due to these numerous adverse possibilities, buyers are rightfully concerned about the "downsides" of an online transaction (Pavlou, Liang \& Xue, 2007).

In the context of internet shopping, risk is a relevant situational parameter in that (1) there is uncertainty about the outcome of an internet shopping transaction, (2) the outcome depends on the behavior of the internet merchant, which is not within the consumer's purview and control, and (3) the harm of an undesirable outcome may be greater than the benefits of a successful outcome (Lee \& Turban, 2001).

Given that e-transactions include already mentioned uncertainty for the consumer, trust is the main condition for exchange (Ribbink et al, 2004). Feeling safe while performing transactions over the internet requires a high level of trust in e-merchant. Therefore, building trust in e-transactions is very important and represents a major challenge.

There are many definitions of online trust. Online trust is when a consumer has confidence in an e-merchant's reliability and integrity to perform online transactions successfully (Angriawan \& Thakur, 2008). This definition implies that the e-merchant has the ability to conduct business activities online, that he will not abuse sensitive information, and that he will deliver products or services as promised. Trust is defined as a buyer's intentions to accept vulnerability based on his beliefs that transactions with a seller will meet his confident transaction expectations due to the seller's competence, integrity, and benevolence (Pavlou, Liang \& Xue, 2007). Trust is discussed in the literature as a trait embedded in the person that touches on one's ability to tolerate a certain amount of risk when engaging in a transaction with another party (Sutanonpaiboon \& Abuhamdieh, 2008).

E-merchants must act in the best possible way to overcome consumer perception of uncertainty and risk by building trust, not only on their web sites but also in the wider internet environment. This includes strict elimination of all activities which adversely affect consumers and prevent them from performing e-transactions.

Trusted websites can provide customers with a secure and private online shopping experience. These sites could alleviate customers' concerns about the leakage, unauthorized collection, or the misuse of their private information, promote deep customer loyalty, and help the companies build a positive relationship with their customers while increasing their market share and profits (Lauer \& Deng, 2007). Unfamiliar websites need to establish their trustworthiness, so that the customer will linger. Security seals, reassuring brand logos and privacy policies are cues customers use (Petre, Minocha \& Roberts, 2006).

Ethics plays an important role in e-transactions and online trust. An essential element of ethics is the establishment of trust. However, trust among strangers who need to perform etransaction is something that is very difficult to accomplish. Unfair business practices lead to serious violations of consumer trust. Fraud, lack of concern about the security of etransactions and skepticism are very frequent in e-commerce. Respect and adherence to rules 
and protocols online are an exception (Miller, 2005). Awareness of the importance of establishing ethical conduct is quite high, mainly because the rule of law and its enforcement still lag behind technological developments. The creation of rules of ethical conduct corresponding to the chosen values enables conduct to be regulated. Amongst the ethical factors likely to be of importance, it would appear that assuring e-consumer's privacy, security and e-merchant's accountability would be necessary to build and maintain confidence in conducting business in the e-market (Avshalom, Avshalom \& Arik, 2007).

\section{FACTORS OF ONLINE TRUST}

There are multiple, interrelated dimensions of e-commerce trust. Thus, trust as a willingness to depend on a vendor to deliver on commitments is not the same as trust as a belief that the vendor uses consumer data ethically, or the same as trust as a perception that the internet is technologically secure (McKnight, Choudhury \& Kacmar, 2002). Therefore, each dimension of trust differentially affects the consumer attitudes, as well as the positive or negative shopping behavior. If all dimensions of trust were present, every purchase over the internet would be perfect.

Information privacy concerns and information security concerns make buyers skeptical about online transactions (George, 2002), and they have been viewed as two major barriers to e-commerce adoption (Hoffman, Novak \& Peralta, 1999; Rose, Khoo \& Straub, 1999).

The most important factors for the development of online trust are: website usability, privacy, security, expected product performance, loyalty and electronic customer relationship management (e-CRM) (Angriawan \& Thakur, 2008).

\subsection{Website usability}

Simply put, website usability represents the ease of use. Usability has been defined as "the extent to which a system can be used by specified users to achieve a specified goal with effectiveness, efficiency and satisfaction in a specified context of use" (Petre, Minacha \& Roberts, 2006). Perceived website usefulness, ease of use and security are significant antecedents of initial trust. (Koufaris \& Hampton-Sosa, 2004).

Effective website usability provides a mechanism and information for consumers and helps them to reduce uncertainty. According to this, the website should provide clear information, recommendations and healthy tips, not promises which cannot be kept. In the context of e-commerce, company website is the primary interaction method for the consumer. A high quality website is important because it allows the first contact between e-merchants and users and it is a crucial element in creating the first impression. If users recognize the quality of a certain website, they will assume that e-merchant has positive features and the trust building process will be able to start. On the other hand, inadequate design, slow website loading, various errors and poor navigation greatly affect online trust.

The first impression is very important. Therefore, many companies, engaged in online business, pay special attention to website design and development (Petre, Minacha \& Roberts, 2006). Three factors that can be linked to website design are: reliability, persuasiveness and credibility (Tamimi \& Sebastianelli, 2007).

If the website does not support the basic technical assumption - fast loading, users will access it with great difficulty which, in most cases, leads to their withdrawal. Many emerchants are over-using elements that may cause slow website loading. Website loading is closely linked to the site design, given that the design includes the use of images and other files which, although they serve for the website to look good, greatly slow down its loading. 
Therefore, it is very important to establish a balance between use of these mentioned elements and an acceptable length of website loading.

Website errors are part of daily life. Although they do not seem to be a serious and complex problem, their impact on building trust is significant. They prevent e-merchants to adequately present themselves and their products, and they also do not allow consumers to make purchases via the internet. The most common website errors are primarily website incompleteness (the lack of contact information), use of illegible letters, variegation, use of unnecessary images (and other files), use of hidden and nonexistent links, unnecessary pop-up windows, etc.

When a user visits a certain website and when it is not possible for him to inspect it logically, he will surely give up and leave. Negative characteristics of navigation are mainly reflected in the excessive complexity, inconsistency and poor organization, which greatly affect user trust.

\subsection{Privacy}

In the context of conventional transactions, there is a certain amount of risk involved for the consumer who, for example, may be uncertain about the quality or the durability of a product purchased. However, when it comes to e-transactions, the biggest privacy risk is based on the possibility of another's opportunistic acquisition and use of this personal information. (Dinev \& Hart, 2006). E-transactions almost always require the exchange of sensitive personal and financial information. E-transactions involve highly delicate information that consumers will not share with e-merchants if they believe that it will invade their privacy. No information is secure and no institution is immune to the possibility of abuse (Caldwell, 2005). Therefore, privacy is an extremely important issue for the development of online trust. It requires lots of security mechanisms and technological control. Privacy is about a merchant's policies on customer information management. The merchant's information management can include usage tracking and data collection, choice, and the sharing of information with third parties (Belanger, Hiller \& Smith, 2002). The main privacy problems are related to data collection, third party data collection, data storage, data sharing and marketing communication (Pollach, 2007). Unfortunately, many companies are abusing consumer information in order to make a profit, which consumers consider to be direct invasion of their privacy. (Culnan \& Armstrong, 1999).

It is clear that consumers do not trust sellers who are not able to protect their information or who cannot adequately manage them. Trust mediates the relationship between privacy and behavioral intention to make an online transaction (Liu et al, 2004). As technologies for data collection and analyzing are becoming more sophisticated, the concern for privacy among consumers constantly grows.

Online privacy concerns the focus on the protection of important consumer information such as name, address, telephone number and financial information. In order to build consumer trust, e-merchants should strongly indicate that collected information at their websites would be used in a fair and responsible manner. Many e-merchants comply and have privacy policies on their websites in order to inform consumers about consumer information management. Although e-merchants behave fairly in this case, ethical behavior cannot be claimed for a third party that may arise in the process. This situation puts the emphasis on the security issue, which will be discussed later.

A factor that greatly affects consumer trust online is the level of control they have over their data (Hoffman, Novak \& Peralta, 1999). Therefore, it is very important for consumers to perceive a certain company as credible and to recognize its true efforts to protect their data. To achieve this goal, many companies upgrade their rules with various privacy seals. The 
more belief consumers have in a company, the more likely they are to do shopping on its website, visit it again or recommend it to others.

\subsection{Security}

E-commerce security issues are related to e-merchants' abilities to protect their online transaction systems. Consumers must be convinced that the company has the ability and willingness to protect their financial information from security vulnerabilities in order for ecommerce to reach full potential. (Pavlou, Liang \& Xue, 2007). Information security is considered the most critical concern for those who do not purchase online (Yang \& Jun, 2002). Security threats include destruction, disclosure, modification of data, denial of service, and/or fraud and abuse (Kalakota \& Whinston, 1996).

Security refers to confidentiality and completeness of personal information, computer security, web and e-mail traffic secrecy. In order to achieve a certain level of security, it is necessary to install some protection programs. It is clear that information cannot travel directly from sender to recipient, but rather via various network nodes, which in turn can lead to message interception. Among other things, encryption systems are very important because they convert data into encrypted form before sending them over the internet, which prevents unauthorized access. Secure transaction methods using encryption and other technologies have existed for some time, yet the perceived risk of internet transactions is still significant (Salam et al, 2005). The mere installation of modern safety programs is not sufficient for a satisfactory security level because it is known that no security system can be $100 \%$ foolproof. There must also be a certain amount of knowledge in the form of IT literacy and awareness in order to successfully avoid many suspicious situations on the internet that could greatly impair the users' safety (opening unsafe and hazardous sites and giving personal data, running suspicious programs, opening e-mails from unknown senders).

\subsection{Expected product performance}

Online, customers can't look a sales clerk in the eye, can't size up the physical space of a store or office, and can't see and touch products. They have to rely on images and promises, and if they don't trust the company presenting those images and promises, they'll shop elsewhere. (Reichheld \& Schefter, 2000). Therefore, e-merchants' integrity (which is closely linked to reputation) is of great importance and forms the basis for this factor. Consumers, in some way, identify e-merchant's integrity with product performance because, since they cannot see the product in person, e-merchant claims are the only information they can get.

\subsection{Loyalty}

Loyalty is defined as a customer's preference towards an e-merchant that results in repeat buying behavior (Srinivasan, Anderson, \& Ponnavolu, 2002). Loyal customers are considered extremely valuable for e-commerce, and loyalty is generally associated with higher levels of service quality (Ribbink et al, 2004).

Loyalty is primarily manifested through the increased number of e-transaction, openness toward new products and participation in programs that require more personal (and other) information. The more online trust consumers have, the higher level of loyalty can be created. Although technology plays a role of great importance, technology alone is not enough to build loyalty; loyalty is achieved through superior shopping experience.

Building superior customer loyalty is no longer just one of many ways to boost profits. Today it is essential for survival (Reichheld \& Schefter, 2000).

\subsection{Electronic customer relationship management (E-CRM)}


E-CRM refers to the marketing activities, tools and techniques delivered via the internet which includes e-mail, world wide web, chat room, e-forums etc. bearing on locating, building and improving long-term customer relationships (Lee-Kelley, Gilbert \& Mannicom, 2003). It is a general strategy supported by information technology which assists companies to build powerful, personalized and mutually beneficial relationship, increase conversion rate, and achieve more efficient sales.

One of the reasons for the great popularity of e-CRM is the fact that digital channels, besides e-transactions, may also provide a unique positive shopping experience. The high level of interaction is another feature of e-CRM that greatly helps companies to properly respond to customer requests or problems and to achieve and maintain long-term relationship. The basis of e-CRM is to enable an organization to treat each customer as an individual, which is a goal that is very difficult to achieve. E-merchants serve a wide range of consumers and good individual relationship with each of them can be very important. It has already been proven that e-CRM has positive effects on customer retention and customer share development (Verhoef, 2003). It is also clear that different types of interaction provide different levels of trust (Angriawan \& Thakur, 2008). CRM strategies such as personalization, one-to-one marketing, reliability, customer-control and efficient customer services aim to maximize customer satisfaction, retention and loyalty - and, hence, profitability for the organization (Petre, Minocha \& Roberts, 2006).

\section{METHODOLOGY AND DATA}

The goal of this study was to understand and explain factors that have the greatest influence on users in carrying out e-transactions and to define a model of trust in etransactions.

The authors conducted the research among Internet users in Bosnia and Herzegovina in February 2010.

The questionnaire was developed by the authors based on research by Angriawan and Thakur's (2008). It included multiple-choice questions (two questions) expressing attitude rating from 1 to 5, where 1 means „strongly disagree“ and 5 ,strongly agree“ (19 questions), two open-ended questions, as well as five questions related to socio-demographic status.

Data were collected using GoogleDocs, whereby a link with the survey was sent to 1,000 e-mail addresses in two waves. A total of 512 responses was collected; i.e. the rate of response was $51.2 \%$.

\subsection{Sample structure}

The sample structure by various socio-demographic characteristics is shown in the following table. 
Table 1. Sample structure

\begin{tabular}{|c|c|c|}
\hline \multicolumn{2}{|c|}{ Socio-demographic characteristics } & $\%$ \\
\hline \multirow{2}{*}{ Gender } & Male & 45.5 \\
\hline & Female & 54.5 \\
\hline \multirow{5}{*}{ Age } & Up to 25 & 62.1 \\
\hline & $26-35$ & 25.6 \\
\hline & $36-45$ & 7.6 \\
\hline & $46-55$ & 3.9 \\
\hline & Over 55 & 0.8 \\
\hline \multirow{4}{*}{ Qualifications } & College & 9.8 \\
\hline & High-school & 34.8 \\
\hline & University-educated & 51.7 \\
\hline & Master or $\mathrm{PhD}$ & 3.7 \\
\hline \multirow{5}{*}{ Income } & Up to 250 EUR & 39.8 \\
\hline & 250-500 EUR & 24.0 \\
\hline & 500-750 EUR & 19.3 \\
\hline & 750-1000 EUR & 10.5 \\
\hline & More than 1000 EUR & 6.3 \\
\hline
\end{tabular}

In terms of sample structure, it is obvious that sample is representative in terms of gender and heterogeneous in all other socio-demographic aspects. The sample structure by income reflects the standard of living in the B-H society.

\subsection{Variables and constructs analyzed in the research}

The basis for developing the questionnaire used for the research is Angriawan and Thakur's (2008) model, which classifies factors affecting trust in e-transactions into five categories: website usability, privacy, security, expected product performance, loyalty, and eCRM, which was explained in the second section of the paper. 
The research used the following variables - constructs:

o website usability (construct that includes 5 manifest variables),

o privacy (construct including 3 manifest variables),

o security (construct made up of 2 manifest variables),

0 expected product performance (construct made up of 2 manifest variables), and

o electronic customer relation management, i.e. e-CRM.

Besides, the research tracked other variables related to the described constructs.

The importance of each of them was examined in order to understand whether the listed factors affect online trust and loyalty, to what extent and whether their improvement may increase users' trust in e-transactions and ensure their loyalty.

In order to determine and test correlations between the obtained ratings for the importance of individual constructs, the following research hypotheses were defined:

1. There is a positively-directed correlation between website usability and online trust.

2. There is a positively-directed correlation between expected product performance and online trust.

3. There is a positively-directed correlation between privacy and online trust.

4. There is a positively-directed correlation between security and online trust.

5. There is a positively-directed correlation between online trust and loyalty.

6. There is a positively-directed correlation between online trust and e-CRM.

\section{RESEARCH FINDINGS AND DISCUSSION}

Research results reveal that 55\% respondents do not carry out e-transactions, and state the following reasons for that: lack of security when paying, threat to privacy, i.e. access to personal data, poorly organized and over-complicated website, lack of face-to-face interaction, and impossibility to check the product's physical characteristics before delivery, as well as lack of information. What is interesting is that many respondents also describe the impossibility of control, i.e. bigger spending when purchasing over the internet than by traditional shopping as a reason for not carrying out e-transactions.

Research results also show that $45 \%$ respondents actually carry out e-transactions, most frequently purchases, sales, and e-banking. The reasons stated include simplicity, speed and greater availability. In terms of frequency, $12 \%$ respondents carry out e-transactions a few times a week, $11 \%$ respondents carry out transactions once a week and considers them an easier way than the traditional one. A total of $29 \%$ respondents ventures on e-transactions once a month, mostly when it comes to paying bills online or monthly grocery purchasing, while $19 \%$ do so once a year. The remaining $29 \%$ refer to respondents whose e-transactions vary too much due to, for instance, money they have at the moment or changes in opinion and needs. 


\subsection{Descriptive statistics}

The following table shows the descriptive statistics parameters we observed for the questionnaire questions (as separate variables).

Table 2. Descriptive statistics ${ }^{4}$

\begin{tabular}{|c|c|c|c|c|c|}
\hline & Descriptive statistics parameters & $\min$ & $\begin{array}{c}\mathrm{ma} \\
\mathrm{x}\end{array}$ & $\begin{array}{l}\text { averag } \\
\text { e }\end{array}$ & $\begin{array}{c}\text { standard } \\
\text { deviatio } \\
\mathrm{n}\end{array}$ \\
\hline $\begin{array}{l}\text { ONLINE } \\
\text { TRUST }\end{array}$ & $\begin{array}{l}\text { Trust in the company - seller is } \\
\text { important in case of e-transactions. }\end{array}$ & 1 & 5 & 4.63 & 0.84 \\
\hline \multirow{5}{*}{$\begin{array}{l}\text { WEBSITE } \\
\text { USABILITY }\end{array}$} & $\begin{array}{l}\text { Company - seller's website usability } \\
\text { (ease of use) is important in case of e- } \\
\text { transactions. }\end{array}$ & 1 & 5 & 4.42 & 0.84 \\
\hline & $\begin{array}{l}\text { My first impression depends on the } \\
\text { website design. }\end{array}$ & 1 & 5 & 3.75 & 1.06 \\
\hline & $\begin{array}{l}\text { Slow website loading results in giving up } \\
\text { the browsing. }\end{array}$ & 1 & 5 & 3.73 & 1.10 \\
\hline & $\begin{array}{l}\text { Poor navigation results in my giving } \\
\text { browsing up. }\end{array}$ & 1 & 5 & 3.72 & 1.06 \\
\hline & $\begin{array}{l}\text { Website should provide information that } \\
\text { help decrease uncertainty related to e- } \\
\text { transactions. }\end{array}$ & 1 & 5 & 4.60 & 0.76 \\
\hline \multirow{3}{*}{ PRIVACY } & $\begin{array}{l}\text { Privacy in important in case of e- } \\
\text { transactions. }\end{array}$ & 1 & 5 & 4.81 & 0.63 \\
\hline & $\begin{array}{l}\text { Distrust in e-transactions increases with } \\
\text { the possibility of sharing my sensitive } \\
\text { information with a third party. }\end{array}$ & 1 & 5 & 4.56 & 0.85 \\
\hline & $\begin{array}{l}\text { The stricter the rules on online privacy, } \\
\text { the greater chances of my carrying out the } \\
\text { transaction. }\end{array}$ & 1 & 5 & 4.43 & 0.85 \\
\hline \multirow[b]{2}{*}{ SECURITY } & $\begin{array}{l}\text { Security is important in case of e- } \\
\text { transactions. }\end{array}$ & 1 & 5 & 4.85 & 0.55 \\
\hline & $\begin{array}{l}\text { I feel insecure when exchanging sensitive } \\
\text { information over the internet due to } \\
\text { potential abuse. }\end{array}$ & 1 & 5 & 4.19 & 1.06 \\
\hline \multirow{2}{*}{$\begin{array}{l}\text { EXPECTED } \\
\text { PRODUCT } \\
\text { PERFORMANC } \\
\text { E }\end{array}$} & $\begin{array}{l}\text { I would not carry out e-transaction } \\
\text { because I am not able to see the product } \\
\text { until the moment of delivery. }\end{array}$ & 1 & 5 & 3.06 & 1.25 \\
\hline & $\begin{array}{l}\text { Company -seller's integrity affects } \\
\text { building of my online trust. }\end{array}$ & 1 & 5 & 4.26 & 0.84 \\
\hline LOYALTY & $\begin{array}{l}\text { Online trust is the basic factor for } \\
\text { building loyalty to company - seller. }\end{array}$ & 1 & 5 & 3.98 & 1.06 \\
\hline e-CRM & $\begin{array}{l}\text { Online trust increases through a } \\
\text { personalized relationship with the } \\
\text { company - seller. }\end{array}$ & 1 & 5 & 4.13 & 0.94 \\
\hline
\end{tabular}

\footnotetext{
${ }^{4}$ Questions that directly express the importance of individual factors are bolded in the table.
} 
Online trust is viewed as a key differentiating factor that determines the success or failure of internet-based operation. Most users are not willing to approve access to sensitive data to a company they do not trust. It is perfectly understandable, since users fear abuses and frauds. For this reason, it is crucial for users to trust both in the positive outcome of an etransaction and in the company's ability to protect their data from a third party. The average rating of the importance of online trust on a scale from 1 to 5 is 4.63. It can be observed that a high percentage of respondents (79\% of them) rated this factor with 5. It proves that trust is of great importance for users in Bosnia and Herzegovina, and that an e-transaction will not occur in case there is no trust. Companies should act the best they can in order to overcome users' perception of insecurity and risk. This implies strict elimination of any activities that affect users negatively and directly prevent them from carrying out e-transactions.

In the context of e-commerce, the company's website is the main way of interaction. From the described attitudes, we can see that the average rating that dictates the importance of website usability is 4.42 , which means that users definitely pay attention to website quality, which in turn helps them to perceive the company's seriousness and starts the process of trust building. Presented results clearly reveal that an efficient website can indeed generate trust. Good navigation, fast loading, design and providing all the necessary information make up the elements of website usability, and the following analysis shows which of them are decisive for respondents:

o Respondents' views show that information on the website is a usability element they pay the greatest attention to. The average rating on providing information that helps decrease uncertainty is high, and amounts to 4.6. Thus, we can conclude that it is very important for a website to be complete and without errors.

o With respect to poor navigation, the average rating is 3.72 and although it is comparatively high, we expected it to be even higher due to all the collected data on this problem. In any case, users give up browsing if sites are over-complex and poorly organized. It should be pointed out that it is extremely important to use simple navigation.

o Interestingly, slow website loading has a somewhat greater effect on users than problems with navigation. The average rating of this statement is 3.73 , which shows that more users give up browsing if website loading is slow, compared to those who give up due to poor navigation.

o Many companies involved in online business pay a particular attention to investment in website design and its improvements. The general opinion is that, if a website design is poor and uncoordinated, a user will simply not trust in everything it offers. We therefore attempted to examine whether, and to what extent, the first impression depends on the website design, and we obtained unexpected results. Although we believed that the percentage of affirmative answers will be extremely high, opinions vary considerably. What is interesting is that the average rating of this statement is 3.75, which does not follow trends in the least. However, it is understandable after the full analysis of usability elements, since it has already been stated that respondents rated website information as the most important element, which in turn means that its appearance is less important for them.

It has already been pointed out that privacy greatly affects the development of online trust, which is additionally supported by this research results. Respondents are definitely convinced that privacy is important in case of e-transactions, which is proven by the average rating of 4.81. As much as $90 \%$ respondents rated it 5. It is evident that e-transactions include exchange of sensitive information while privacy in this context implies their adequate management. The management involves their use, monitoring, and sharing with a third party. 
We learned that respondents believe that their distrust in e-transactions increases with the possibility of sharing their information with a third party (average rating of 4.56). In this respect, their greatest concern is the purpose they are used for and whether their inboxes will be crammed with unapproved messages. Unethical internet behavior is the cause for this concern, and it is therefore crucial to pay more attention to the protection of their privacy, in order to prevent them from giving up e-transactions. Besides, the stricter the rules of online privacy, the greater chances for success (average rating of 4.43).

Respondents consider security to be the most important factor in case of etransactions, which is proven by the average rating of 4.85 (slightly higher than privacy). Besides, most of them feel insecure when exchanging sensitive information. The main reason for such views is a great degree of distrust in electronic systems in Bosnia and Herzegovina, since it is believed that there is no sufficient degree of protection, and that the risk is too high. In order for e-commerce to reach its full potential, it is necessary to provide adequate security mechanisms that would protect financial and sensitive information and reduce security omissions to a minimum. If applications that support the security codes practice are not sufficiently developed and used, many users will clearly give up e-transactions or, even if they decide to carry them out, will feel a reasonable fear.

Due to the internet specificity, where face-to-face interaction is impossible and where products cannot be seen and touched, users must rely on promises and images. Most present studies show that they give up e-transactions because they do not have the opportunity to see products and make sure of their performance until the very moment of delivery. However, respondents' views on this issue in this research are surprising. The average rating of 3.06 leads to the conclusion that, although many of them believe that there is a possibility of not receiving what they actually ordered, they still carry out e-transactions (naturally - if the requirements concerning privacy and security have been met, which has already been discussed). If the company has a good reputation in these matters, it is also believed that it provides a realistic picture of its products and delivers them with the expected performance (average rating of 4.26).

The internet has changed the old rules of doing business - it is true, but when it comes to a specific factor such as consumer loyalty, old rules are still in place. Loyalty in this context is still related to users' trust and they will certainly, after a superior online experience always stay loyal to the company that provided them with such an experience. Research results, with the average rating of 3.98 reveal that over half of respondents believe that, before they become loyal, companies must gain their trust, which makes sense. They pay attention to the already described factors, which increase trust and make up a whole that cannot function properly if any of them is missing. Only a few of them believe that online trust is not a basic factor in building loyalty to the company - seller.

It is a fact that companies that do not aspire to build long-term relations are in an unenviable position since they cannot fully understand which factors truly increase their satisfaction, successfully initiate repeat purchases and lead to increased trust. The high average rating of 4.13 provides evidence that their online trust increases through the personalized relationship with the company, which refutes all views that in the online world, a personalized relationship is not important for generating trust. 


\subsection{Model of mutual dependence}

Since some constructs have been derived based on the average value of responses to questions pertaining to given constructs, an analysis of reliability ${ }^{5}$ for responses from the questionnaire and derived constructs was performed in the very beginning (Table 3.).

Table 3. Analysis of reliability

\begin{tabular}{|c|c|c|}
\hline & & $\begin{array}{l}\text { Cronbach } \\
\text { alpha }\end{array}$ \\
\hline \multirow{5}{*}{$\begin{array}{l}\text { WEBSITE } \\
\text { USABILITY }\end{array}$} & $\begin{array}{l}\text { Company - seller's website usability (ease of use) } \\
\text { is important in case of e-transactions. }\end{array}$ & \multirow{5}{*}{0.664} \\
\hline & My first impression depends on website design. & \\
\hline & $\begin{array}{l}\text { Slow website loading results in my giving up } \\
\text { browsing. }\end{array}$ & \\
\hline & Poor navigation results in my giving up browsing. & \\
\hline & $\begin{array}{l}\text { Website should provide information that help } \\
\text { decrease uncertainty related to e-transactions. }\end{array}$ & \\
\hline \multirow{3}{*}{ PRIVACY } & Privacy is important in case of e-transactions. & \multirow{3}{*}{0.724} \\
\hline & $\begin{array}{l}\text { Distrust in e-transactions increases with the } \\
\text { possibility of sharing my sensitive information } \\
\text { with a third party. }\end{array}$ & \\
\hline & $\begin{array}{l}\text { The stricter the rules on online privacy, the } \\
\text { greater the chances of my carrying put an e- } \\
\text { transaction. }\end{array}$ & \\
\hline \multirow[b]{2}{*}{ SECURITY } & Security is important in case of e-transactions. & \multirow[b]{2}{*}{0.641} \\
\hline & $\begin{array}{l}\text { I feel insecure when exchanging sensitive } \\
\text { information over the internet due to possible } \\
\text { abuse. }\end{array}$ & \\
\hline \multirow{2}{*}{$\begin{array}{l}\text { EXPECTED } \\
\text { PRODUCT } \\
\text { PERFORMANCE }\end{array}$} & $\begin{array}{l}\text { I would not carry out an e-transaction because I } \\
\text { am not able to see the product until the moment } \\
\text { of its delivery. }\end{array}$ & \multirow[t]{2}{*}{0.670} \\
\hline & $\begin{array}{l}\text { Company - seller's integrity affects building of } \\
\text { my online trust. }\end{array}$ & \\
\hline
\end{tabular}

All the Cronbach alpha values are higher than 0.6, which proves that the assumption of reliability has been satisfied, and that the defined constructs can be analyzed further.

The structural model involves a series of linear regression models that describe how some variables depend on others. These models are called structural equations, while a group of structural equations makes up a structural model. Coefficients describe the way in which the dependent variable depends on the independent variable values and are called path coefficients. We used Amos, software which is part of SPSS package to calculate these coefficients. A model that included the constructs as manifest variables (website usability, privacy, security, expected product performance, and e-CRM), and the obtained results (path coefficients) are presented in Graph 1.

\footnotetext{
${ }^{5}$ Cronbach's alpha is a measure of internal consistency, that is, how closely related a set of items is as a group. A "high" value of alpha is evidence that the items measure an underlying (or latent) construct. Cronbach’s alpha is not a statistical test - it is a coefficient of reliability (or consistency).
} 
Graph 1. Structure model

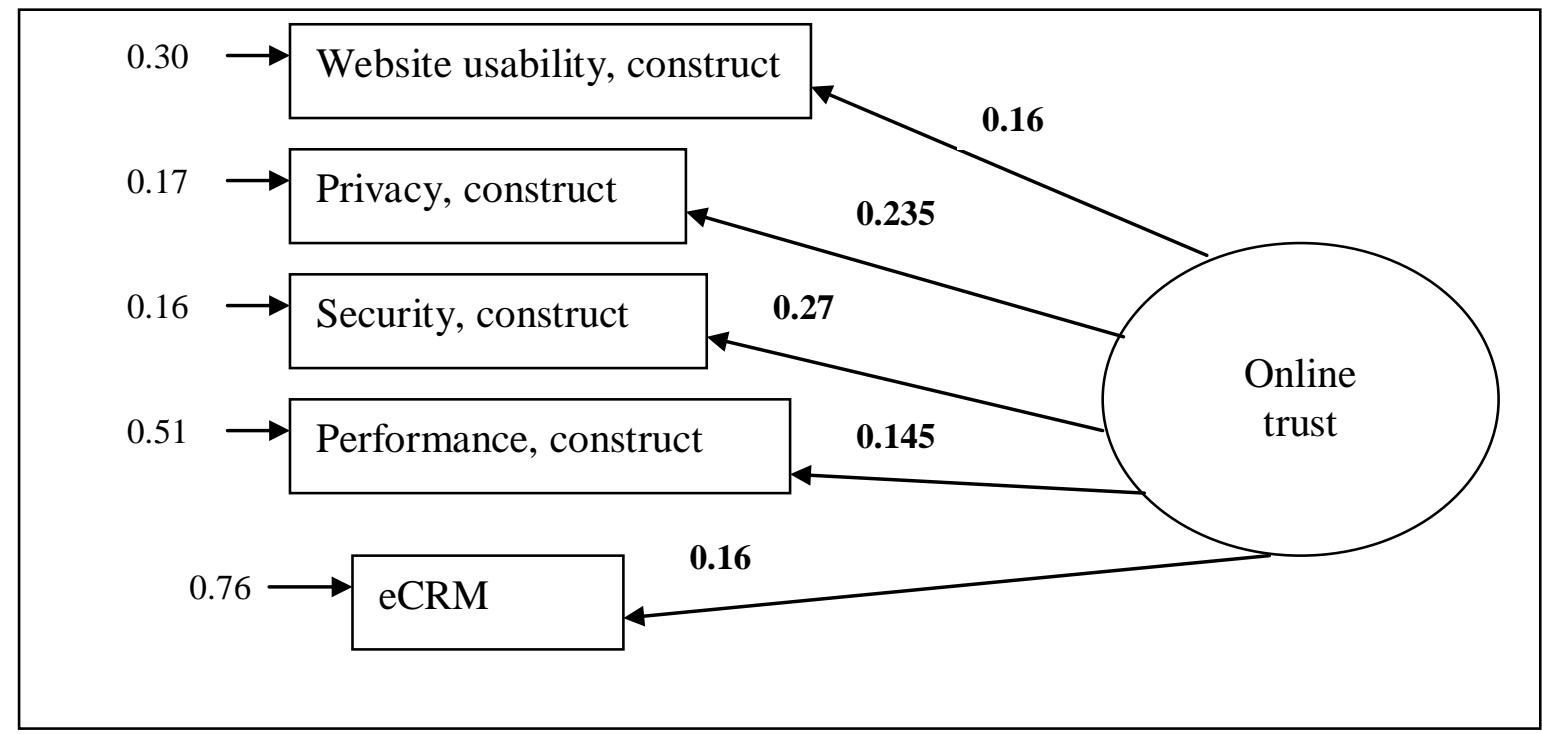

Chi square value for the obtained model is 14.27 with $\mathrm{p}$ value of 0.014 , while the RMSEA value $^{6}$ is 0.06 , which is lower than the critical value of 0.08 . This indicates the adequacy of the obtained model. Since online trust is also directly rated through the questionnaire, the comparison of the original ratings with those that would be obtained using the presented model has been made:

$$
\begin{aligned}
& \text { online trust }(\text { estimated })= \\
& =0.16 \cdot \text { website usability }+0.235 \cdot \text { privacy }+0.275 \cdot \text { security }+0.145 \cdot \text { performance }+0.16 \cdot \text { eCRM }
\end{aligned}
$$

The average value of absolute deviation of the original from rated valued for online trust is 0.197 with standard deviation of 0.263 . When this value is related to the average value of the original rating for the importance of online trust (4.63, cf. Table 2), the model variation coefficient of $4.25 \%$ is obtained, which indicates the significance of the obtained structure model and its applicability in further forecasts.

Similar to Angriawan and Thakur's model, our model also proves a direct correlation between online trust and manifest variables included in the model; however, we cannot directly compare model results (path coefficients), since manifest variables are not included in these structural models in the same way.

In order to check the postulated hypotheses, we calculated partial coefficients of correlation between original ratings for online trust and variables included in the model (Table 4).

\footnotetext{
${ }^{6}$ RMSEA is the root mean square error of approximation. This is test of model fit, good models are considered to have a RMSEA of 0.08 or less.
} 
Table 4. Partial coefficients of correlation with the online trust variable

\begin{tabular}{|l|c|r|}
\hline & r & P value \\
\hline Website usability & 0.098 & 0.039 \\
\hline Privacy & 0.271 & 0.000 \\
\hline Security & 0.202 & 0.000 \\
\hline Performance & 0.112 & 0.011 \\
\hline e-CRM & 0.105 & 0.024 \\
\hline
\end{tabular}

All the obtained correlation coefficients are significant with the first-type error of 5\% ( $p$ value is lower than 0.05 ), which means that the following hypotheses have been proven:

1. There is a positively-directed correlation between website usability and online trust.

2. There is a positively-directed correlation between expected product performance and online trust.

3. There is a positively-directed correlation between privacy and online trust.

4. There is a positively-directed correlation between security and online trust.

5. There is a positively-directed correlation between online trust and e-CRM.

Since the importance of online trust and loyalty was directly rated through the questionnaire, the correlation coefficient was used to analyze correlation between them. The obtained correlation coefficient has the value of 0.42 with $\mathrm{p}$ value 0.000 , which proves the set hypothesis that: There is a positively-directed correlation between online trust and loyalty.

\section{CONCLUSION}

All e-transactions imply a certain degree of uncertainty in terms of their outcome, as well as the exchange of personal and sensitive data. Poor business practices make ecommerce difficult causing dissatisfaction and uncertainty. E-merchants must act in the best possible way in order to overcome consumers' perception of insecurity and risk by building trust. It implies strict elimination of all activities that negatively affect consumers and directly prevent them from carrying out transactions.

The research proved that basic factors of online trust model development include: website usability, privacy, security, expected product performance, loyalty, and electronic customer relations management (e-CRM).

There is a strong mutual correlation among these factors and e-merchants must therefore use an integral holistic approach in their programs of online trust development, building trust with consumers and ensuring security and privacy.

\section{REFERENCES}

Angriawan, A., Thakur, R. (2008), „A Parsimonious Model of the Antecedents and Consequence of Online Trust: An Uncertainty Perspective“, Journal of Internet Commerce, 7 (1): 74-94.

Avshalom, A. M., Avshalom, A., Arik, S. (2007) „Do Ethics Matter to e-Consumers?“, Journal of Internet Commerce, 6 (2): 19-34.

Belanger, F., Hiller, J. S., Smith, W. J. (2002), „Trustworthiness in Electronic Commerce“, Journal of Strategic Information Systems, 11 (3): 245-270.

Caldwell, C. (2005), „The Price of Privacy is High“, Financial Times, April 16/17, pp. 7

Culnan, M.J., Armstrong, P.K. (1999), „Information Privacy Concerns, Procedural Fairness, and Impersonal Trust“, Organization Science, 10 (1): 104-115. 
Dinev, T., Hart, P. (2006), „An Extended Privacy Calculus Model for e-Commerce Transactions“, Information Systems Research, 17 (1): 61-80.

George, J. (2002), „Influences on the Intent to Make Internet Purchases“, Internet Research, 12 (2): 165-180.

Hoffman, D. L., Novak, D. P., Peralta, M. (1999), „Building Consumer Trust Online“, Communications of the ACM, 42 (4): 80-85.

Kalakota, R., Whinston, A. B. (1996), Frontiers of Electronic Commerce, (Addison Wesley).

Koufaris, M., Hampton-Sosa, W. (2004), „The Development of Initial Trust in an Online Company by New Customers“, Information and Management, 41 (3): 377-399.

Lauer, T. W., Deng, X. (2007), „Building Online Trust Through Privacy Practices“, International Journal of Information Security, 6 (5): 323-331.

Lee, M., Turban, E. (2001), „A Trust Model for Consumer Internet Shopping“, International Journal of Electronic Commerce, 6 (1): str. 75-91.

Lee-Kelley, L., Gilbert, D., Mannicom, R. (2003), „How e-CRM Can Enhance Customer Loyalty“, Marketing Intelligence and Planning, 21 (4): 239-248.

Liu, C., Marchewka, J. T., Lu, J., Yu, C. S. (2004), „Beyond Concern: A Privacytrustbehavioral Intention Model of Electronic Commerce“, Information and Management, 42 (1): 127-142.

McKnight, D. H., Choudhury, V., Kacmar, C. (2002), „Developing and Validating Trust Measures for e-Commerce: An Integrative Typology“, Information Systems Research, 13 (3): 334-359.

Miller, K. W. (2005), „Web Standards: Why So Many Stray from the Narrow Path“, Science and Engineering Ethics, 11 (3): 477-479.

Pavlou, P. A., Liang, H., Xue, Y. (2007), „Understanding and Mitigating Uncertainty in Online Exchange Relationships: A Principal Agent Perspective“, MIS Quarterly, 30 (1): 115-143.

Petre, M., Minocha, S., Roberts, D. (2006), „Usability Beyond the Website“, Behaviour and Information Technology, 25 (2): 189-203.

Pollach, I. (2007), „What’s Wrong With Online Privacy Policies?“, Communications of the ACM, 50 (9): 103-108.

Reichheld, F. F., Schefter, P. (2000), e-Loyalty: Your Secret Weapon on the Web, (Harvard Business School Publishing)

Ribbink, D., van Riel, A. C. R., Lilander, V., Streukens, S. (2004), „Comfort Your Online Customer: Quality, Trust and Loyalty on the Internet“, Managing Service Quality, 14 (6): 446-456.

Rose, G., Khoo, H., Straub, D. (1999), „Current Technological Impediments to Business-toConsumer Electronic Commerce“, Communications of the AIS, 1 (5).

Salam, A. F., Iyer, L., Palvia, P., Singh, R. (2005), „Trust in e-Commerce“, Communications of the ACM, 48 (2): 73-77.

Srinivasan, S., Anderson, R., Ponnavolu, K. (2002), „Customer Loyalty in e-Commerce“, Journal of Retailing, 78 (1): 41-50.

Sutanonpaiboon, J., Abuhamdieh, A. (2008), „Factors Influencing Trust in Online Consumerto-Consumer (C2C) Transactions“, Journal of Internet Commerce, 8 (2): 203 - 219.

Tamimi, N., Sebastianelli, R. (2007), „Understanding e-Trust“, Journal of Information Privacy and Security, 3 (2): str. 3-17.

Verhoef, P. C. (2003), „Understanding the Effect of Customer Relationship Management Efforts on Customer Retention and Customer Share Development“, Journal of Marketing, 67 (4): 30-45.

Yang, Z., Jun, M. (2002), „Consumer Perception of e-Service Quality: From Internet Purchaser and Non-Purchaser Perspectives”, Journal of Business Strategies, 19 (1):. 19-41. 


\section{MODEL POVJERENJA U E-TRANSAKCIJE}

\section{SAŽETAK}

Trend razvoja e-trgovine osim značajnih koristi kreira $i$ dosta izazova u smislu razvoja povjerenja između kompanije i potrošača. Nedostatak povjerenja vodi ka neobavljanju etransakcija. Cilj ovog rada jeste identifikacija i objašnjenje najvažnijih faktora modela koji utiču na povećanje povjerenja korisnika u e-transakcije. Osim analize dostupnih radova iz ove oblasti provedeno je i terensko istraživanje na uzorku od 512 ispitanika uz pomoć online ankete. Nalazi istraživanja potvrđuju da su osnovni faktori modela online povjerenja: upotrebljivost web stranice, privatnost, sigurnost, očekivane performanse proizvoda, lojalnost i elektronsko upravljanje odnosom s klijentima (e-CRM).

Ključne riječi: e-transakcije, e-trgovina, povjerenje 